\title{
Is There A Need For A Free Trade Agreement Between The European Union And Gulf Cooperation Council?
}

M. Anaam Hashmi, Minnesota State University, USA

Fahad Al-Eatani, King Abdulaziz University, Saudi Arabia

Fareed Shaikh, King Abdulaziz University, Saudi Arabia

\begin{abstract}
The need for a free trade agreement between the European Union (EU) and Gulf Cooperation Council (GCC) is analyzed in this research project. Trade flows between these two economic blocs are studied to understand the importance of trade for these respective blocs. Failure of the free trade agreement negotiation is attributed to the lack of economic focus and the EU demands to improve human rights in GCC member countries. Based on the secondary sources and data analyses, the primary interest of both economic blocs is to enhance geopolitical influence and not boasting bilateral trade. Despite recent failures, both sides are still committed to increased partnership in the future. It is concluded that an EU-GCC free trade area may be essential for increased cooperation in economic, as well as geopolitical, security, environmental, and cultural arenas.
\end{abstract}

Keywords: Free Trade Agreement; Gulf Cooperation Council; European Union; Trade-Flow; Economic Blocs

\section{INTRODUCTION}

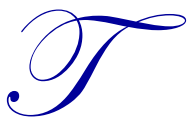

he Gulf Cooperation Council (GCC) consists of Bahrain, Kuwait, Oman, Qatar, Saudi Arabia, and the United Arab Emirates. GCC was created in May 1981 and has aspirations to introduce a single currency before 2015. GCC has been a common market since January 2008. The common market grants national treatment to all GCC firms and citizens in other GCC member countries and removes all barriers to cross-country investment and services trade. The GCC member countries are major trading partners with the European Union (EU) and they have tried to negotiate a Free Trade Agreement (FTA) with the EU stimulated by the increasing number of young workers entering the labor force in the GCC region and ongoing structural reforms to reduce their reliance on their public sector. The EU-GCC free trade agreement has great potential to stimulate GCC economies with some industries enjoying increased export demand in the European countries. A free trade regime may also have negative ramifications for selected GCC industries facing import competition from corporations from EU member countries. All six GCC countries currently benefit from preferential access to the EU market under the EU's Generalized Scheme of Preferences. Projected economic and political benefits to the EU member countries are still debated.

The relations between the EU and the GCC countries hold great potential. In the past, both regions acknowledged their respective international role; however, they were bogged down by the negotiations on the details of FTA and definition of sensitive industry not to be a part of any liberal trade regime. The EU-GCC relationship has the potential to go far beyond the economic benefits, as the EU and the Arabian Gulf countries share many common interests with regard to regional security, as well as political, economic, environmental, and cultural issues. Conclusion and implementation of EU-GCC free trade agreement is a necessary step to move forward and cooperate on non-economic issues. 


\section{OVERVIEW OF THE EU TRADE AGREEMENTS}

The EU trade policy has thus far been mostly characterized by two main orientations. The first one has been multilateralism. The EU emphasizes multilateral negotiations and had implemented a de facto memorandum on bilateral agreements in the 1990s. The other major feature of the EU's trade policy, and the main exemption to multilateralism, has been the ambitious set of preferences granted to selected developing countries. In this area, the EU has long negotiated non-reciprocal preferences agreements, with a strong bias towards former colonies of EU member countries and friendly developing countries. This has resulted in special tariffs for overseas territories, for African-Caribbean and Pacific countries under the Cotonou agreement and into the Generalized System of Preferences (GSP). Along with the Cotonou agreement, the EU has also negotiated a preferential trade agreement with several African countries (Hinkle, Hoppe, \& Newfarmer, 2006). For a long time, agreements with North African countries also fell into this category (they have now been turned into reciprocal agreements). GSP tariffs apply to all developing and transition countries, but they differ a lot between various developing countries (whose exports do not face any tariff), Central American and Andean countries (who face tariffs that are quite similar to the ones faced by ACP countries under the GSP+), and most other developing and transition countries who enjoy only limited tariff reductions under the regular GSP. Finally, the EU also uses tariff reduction as a way to support troubled states in an attempt to help stabilization (such as Balkan countries, Palestinian state). The EU has a long history of bilateral and multilateral trade agreements and the agreement with GCC is part of this ongoing effort. A brief summary of these agreements is provided in the Appendix.

Persson (2008) assessed the potential benefits from trade facilitation in terms of increased trade flows, both on average and, specifically, for the six regional groupings of African, Caribbean, and Pacific (ACP) countries negotiating Economic Partnership Agreements (EPAs) with the EU. The study uses data from the World Bank's Doing Business Database on the time required to export or import as indicators of cross-border transaction costs. This study found different results for different ACP regions, and not all regions have enjoyed similar benefits by trading with EU countries.

\section{EU-GCC FREE TRADE AGREEMENT}

Twenty-four years have passed since the EU-GCC Cooperation Agreement was signed in 1988 to evaluate what has been accomplished and to analyze what the experiences of the past years might mean for any future effort. In 1991, the European Union Council authorized the Commission to negotiate an FTA with the countries of the GCC. The conclusion of such agreement was made conditional upon the establishment of a customs union among the GCC member countries. In December 2001, the GCC agreed to establish a customs union by January 1, 2003, and to simplify the Common External Tariff (CET) to two groups - products that are exempted of duties and products with 5\% duty. This decision encouraged the GCC and the EU to proceed more rapidly in the negotiations. No doubt, the announcement by GCC Secretary-General, Abdulrahman Al-Attiyah, at the end of 2008 of the unilateral suspension of the FTA negotiations, took the world by surprise, but it should not be surprising to EU policymakers.

The fact was that the talks, although complicated and detailed, had been going on for too long with neverending suggestions since 2003, and this would be the year when a deal would finally be sealed after creation of a GCC customs union. The GCC also felt that it was the one being asked to make all the concessions, and those negotiations were increasingly tense where the EU demanded and the GCC had to give in. Without sufficient flexibility from the EU side, the continuation of talks became untenable; thus, a decision to unilaterally suspend negotiations was taken by the GCC side (Toledo, 2011). One of the reasons for lack of progress on economic issues is the increased emphasis on cultural and political issues in the GCC member countries.

Antkiewicz and Momani (2009) analyzed the motives of the EU in their trade negotiation with the GCC member countries because this may be the first trade agreement between two well-established economic blocs. The authors identified that any FTA will have an insignificant effect on trade creation for the EU, and the EU has no economic gain in concluding an FTA with the GCC member countries. Antkiewicz and Momani (2009) concluded that the EU's motives are mostly non-economic, such as expanding geopolitical influence, human rights issues, and ensuring regional security. This conclusion is supported by another research study conducted by Nonneman (2006). 
Nonneman (2006) analyzed the evolution of EU-GCC trade negotiations and concluded that political events, such as the first Gulf War (1991) and the second Gulf War (2003), were the main catalysts of progress in trade negotiations; therefore, political reasons have been dominating the trade talks between these two economic blocs. Nonneman (2006) also concluded that the EU does not consider an FTA agreement to be economically beneficial to their member countries.

\section{RESEARCH METHODOLOGY}

Some of the questions dealing with current and future EU-GCC trade relationships and possible conclusion of an FTA are the focus of this research. Secondary data sources are utilized to understand the past EU-GCC trade relationships and the importance of bilateral trade to each other. These questions may provide a new impetus to any future negotiations.

\section{Research Questions}

Question \# 1: What is the current status of EU and GCC Free Trade Agreement (FTA) negotiation and partnership?

Question \# 2: What are the anticipated gains for EU and GCC member countries?

\section{ANALYSES OF EU-GCC TRADE DATA}

The data analyses and literature review presented in this study helped in answering both research questions. Trade data of the EU and GCC member countries over the five-year period (2007-2011) and the EU's trade data with key trading partners, are summarized in Tables 1,2 and 3. The purpose of the data analyses is to understand the importance and interdependence of both economic blocs to each other.

A careful analysis of Table 1 reveals the fact that the GCC is a less important partner for the EU. During 2007-2011, the share of imports from the GCC was between 1.9 and 2.4\% of total EU imports. Most of this import is petroleum and its by-products that have entered into EU countries without significant barriers. Reduction in the EU barriers does not guarantee a significant increase of EU imports. The share of EU exports to GCC during the 2007-2011 period was between 4.9 and 5.2\% of total EU exports, with most of the EU exports subject to only five percent uniform tariff. Over 400 tariff lines - mainly food categories and industrial inputs - carry no tariff at all at GCC entry points. At the same time, GCC member countries are allowed to nominate a list of "protected commodities" on which they charge a tariff rate ranging from 12 to 20 percent, but these protected commodities are an insignificant part of GCC imports. FTA between the EU and the GCC has the potential to reduce tariffs on protected commodities, but the potential benefit to the EU member countries is unclear. EU has been enjoying a trade surplus with GCC countries as evident in available data shown in Table 1.

Table 1: EU Trade Balance with the GCC

\begin{tabular}{|l|c|c|c|c|c|}
\hline Period & $\begin{array}{c}\text { EU Imports } \\
(\text { Millions of } \boldsymbol{€} \text { ) }\end{array}$ & $\begin{array}{c}\text { Share of Total EU } \\
\text { Imports (\%) }\end{array}$ & $\begin{array}{c}\text { EU Exports } \\
\text { (Millions of } \boldsymbol{€} \text { ) }\end{array}$ & $\begin{array}{c}\text { Share of Total } \\
\text { EU Exports (\%) }\end{array}$ & $\begin{array}{c}\text { EU-GCC Trade } \\
\text { Balance (Millions of } \boldsymbol{€} \text { ) }\end{array}$ \\
\hline 2007 & 31,882 & 2.2 & 60,946 & 4.9 & 28,063 \\
\hline 2008 & 37,378 & 2.4 & 68,484 & 5.2 & 31,109 \\
\hline 2009 & 22,337 & 1.8 & 57,100 & 5.2 & 34,763 \\
\hline 2010 & 35,010 & 2.3 & 65,022 & 4.8 & 30,011 \\
\hline 2011 & 56,379 & 3.3 & 72,255 & 4.7 & 15,875 \\
\hline
\end{tabular}

Source: Direction of Trade Statistics, International Monetary Fund, December 2012

Based on the information presented in Table 2, the nature of trade relations for GCC member countries is quite different. At the end of 2011, EU countries' import share from the GCC countries was merely $3.3 \%$, which makes the entire GCC the seventh import partner of the EU. The EU's import share from China, Russia, and the United States was $17.3 \%, 11.8 \%$, and $10.9 \%$, respectively. In 2011, most of the EU's exports were destined for the United States (17.0\% share) and the GCC countries were the sixth major export partner with only representing $4.7 \%$ of the total EU exports. The EU's combined trade data are tabulated in Table 3 and the data confirmed earlier findings that the GCC represent only $4.0 \%$ of the total EU trade, making the GCC the sixth important trading 
partner. The United States, China, and Russia are the top three trading EU partners. On the other hand, EU is the most important trading partner for GCC with about 30\% import from the EU countries and about 10\% export to EU countries (Direction of Trade Statistics, 2012). Based on the trade volume, the EU is more important for GCC, while GCC is comparatively insignificant for EU policymakers; this reality is manifested in bilateral free trade agreement negotiation. Reduction of trade barriers, as a result of a free trade agreement, may not alter the trade flow dynamics between these two economic blocs.

Table 2: The European Union's Major Import and Export Partners (2011)

\begin{tabular}{|l|c|c|c|c|c|}
\hline $\begin{array}{c}\text { Import } \\
\text { Partners }\end{array}$ & $\begin{array}{c}\text { Import Volume } \\
\text { (Millions of } \boldsymbol{\epsilon})\end{array}$ & $\begin{array}{c}\text { Percentage of } \\
\text { World (\%) }\end{array}$ & Export Partners & $\begin{array}{c}\text { Export Volume } \\
\text { (Millions of } \boldsymbol{\text { ) }}\end{array}$ & $\begin{array}{c}\text { Percentage of } \\
\text { World (\%) }\end{array}$ \\
\hline China & 292,071 & 17.3 & U.S. & 260,567 & 17.0 \\
\hline Russia & 198,178 & 11.8 & China & 136,217 & 8.9 \\
\hline U.S. & 184,141 & 10.9 & Switzerland & 121,691 & 7.8 \\
\hline Norway & 93,529 & 5.6 & Russia & 108,449 & 7.1 \\
\hline Switzerland & 91,204 & 5.4 & Turkey & 72,588 & 4.7 \\
\hline Japan & 67,445 & 4.0 & $G C C$ & 72,255 & 4.7 \\
\hline$G C C$ & 56,379 & 3.3 & & & \\
\hline
\end{tabular}

Source: Direction of Trade Statistics, International Monetary Fund, December 2012

Table 3: Importance of the EU's Total Trade Partners (2011)

\begin{tabular}{|l|c|c|}
\hline \multicolumn{1}{|c|}{ Total Trade Partners } & Total Trade Volume (Millions Of $\boldsymbol{\epsilon}$ ) & Percentage Of World (\%) \\
\hline U.S. & 444,708 & 13.8 \\
\hline China & 428,288 & 9.3 \\
\hline Russia & 306,627 & 6.5 \\
\hline Switzerland & 212,895 & 4.4 \\
\hline Norway & 140,059 & 4.0 \\
\hline$G C C$ & 128,634 & \\
\hline
\end{tabular}

Source: Direction of Trade Statistics, International Monetary Fund, December 2012

Trade data analyses shed new light on the nature of the trade relationship between these two economic blocs and the issues raised in Question \# 1. The issues raised in Question \# 2 are studied in the following section.

\section{ANTICIPATED GAINS FOR EU AND GCC MEMBER COUNTRIES}

DeRosa and Kernohan (2004) analyzed the economic impacts of a proposed FTA on GCC and EU member countries. The study concluded that the FTA will "appreciably expand trade and improve economic welfare in the GCC countries, with little significant economic impact on the EU." DeRosa and Kernohan further concluded that a reduction of 5\% GCC import tariff - to about 3\% - would ensure the near-maximum trade performance between the EU and the GCC. Toledo (2011) studied the impact of EU-GCC FTA on the UAE economy and concluded a noticeable price change across United Arab Emirates (UAE) industries and an increase in factor mobility in the country. The study is inconclusive whether UAE industries will be adversely affected by FTA.

A comprehensive study on the economic gains by Price Waterhouse Coopers concluded that the GCC will gain most from an FTA; however, an EU-GCC free trade area is not likely to change trade flows or the composition of mutual trade, to a large extent (Price Waterhouse Coopers, 2004). An FTA may slightly improve economic welfare in the GCC with aggregate welfare gains of 2.7-2.9\%; however, the FTA would not have a major impact on the EU's economy (Price Waterhouse Coopers, 2004).

\section{CURRENT STATUS OF EU AND GCC FREE TRADE AGREEMENT}

While examining both the positives and the negatives, it quickly became clear in the deliberations that the failure to make any headway in the negotiations over an FTA was seen as the prime example highlighting the shortcomings, even failure, in strategic EU-GCC relations. The inability of both sides to bring the talks to a fruitful end after, as has been argued, two decades of discussions was seen as indicative of the fact that institutional ties had not developed sufficiently. 
It must be mentioned that such characterization is not completely accurate, especially if one takes a more comprehensive look at how EU-GCC relations have developed. Even as far as the suspended FTA talks are concerned, one could take a different perspective and argue that the fact that the two sides were engaged in serious negotiations was a direct result of increased institutional relations. In addition, to view the suspension of the negotiations by the GCC as an end by itself is simply short-sighted. It is a temporary measure that can be reversed. Here, one should again not evaluate GCC-EU ties from the perspective of the FTA that has been in place for more than two decades, but for which so far there is apparently very little to show for. This would be unfair because for much of that period, the two sides were simply not ready - institutionally or politically - to engage in a substantive manner in such a complicated matter as a free trade area agreement (Koch \& Stenberg, 2010).

In fact, on all fronts outside of the FTA, relations between the EU and the GCC have strengthened. The overall trade balance has been growing and the EU remains the GCC's largest trading partner (Table 1). An annual ministerial council meeting has been held regularly and the communiqués issued reveal a relative convergence of views on most issues. There are currently numerous expert meetings that are convened in the areas of environmental cooperation, energy, education, and combating money laundering and terrorist financing. A European Commission office has existed in Riyadh since 2004 and there are proposals being considered to open additional offices in other GCC countries. Regular exchanges also take place with regard to many of the GCC's integration plans. There have even been consultations as the GCC prepares to develop its own neighborhood policy and to learn from European experiences. All of this is supplemented by increased contact at the private and non-governmental levels. Far from being a picture of failure, it can thus be argued that GCC-EU ties are quite vibrant, especially if one considers the past few years. In all aspects, Europe remains a central region and partner for the Gulf region.

Encouraging is the fact that despite a formal suspension of the negotiations in 2008, informal discussions have continued with several sessions having taken place. This followed a commitment at the joint council meeting in 2009, held at Muscat to continue with those discussions. The joint communiqué reiterated the desire of both sides to continue consultations and announced cooperation in dealing with regional and international issues, including Iraq, Iran, terrorism, non-proliferation of weapons of mass destructions, piracy, and environmental issues (The Cooperation Council, 2009). It is widely expected that official negotiations will only resume once there is a clear indication that these can be concluded successfully and that agreement is likely. In this context, the issue of export duties appears to be the central sticking point. Human rights and democracy have dominated the headlines as being the main obstacle with the GCC side seeing this as interference in their domestic sovereignty; this should be seen as a minor issue that can be resolved through diplomatic bargaining. The notion that the EU reserves the right to suspend the agreement (or parts thereof) in case of alleged human rights infractions is one where GCC countries are pressing for a different language to be applied. This, however, is not a fundamental disagreement that will cause the negotiations to fail.

On a positive note, institutional ties between the two blocs have emerged at several levels. On the multilateral side, there are the relations between the European Commission and the GCC states and between the EU Presidency and that of the GCC (Koch \& Stenberg, 2010). Similarly, relations have proceeded at the bilateral level between individual member states. As far as the GCC is concerned, decision-making is still taking place at the individual national state level rather than within the framework of the multilateral GCC. Past experiences have shown that during presidencies that have both the capacity and determination to focus on the development of GCCEU ties, such as those of Germany in the first half of 2007 and France in the second half of 2008, progress can be made and institutional ties can be advanced. Meanwhile, during other presidencies, this is not necessarily the case and EU-GCC ties fall into a certain limbo (Koch \& Stenberg, 2010).

Nevertheless, relations have not developed to their full potential and what has been achieved can, at best, be seen as representing a good starting point. As a result, there is a general consensus that a much more open and concrete commitment by both sides needs to materialize and that both have to make a more concerted effort to substantiate relations with more than words and simple suggestions.

\section{CONCLUSIONS AND FUTURE DIRECTIONS}

After twenty-four years, EU-GCC member countries are unable to reach a treaty on a Free Trade Agreement (FTA). The Joint Council meeting held in Muscat at the end of April 2009 underlined the broad 
commitment of both sides to broaden and deepen relations outside the scope of an FTA. It is therefore imperative that continued concerted efforts are undertaken to resolve outstanding issues and to put forward compromise suggestions that can undo the present deadlock.

There is a perception within the GCC that, up to this point, the EU has contributed little in terms of helping to integrate the GCC into global markets and that in terms of policy-exploring opportunities in the EU-GCC relationship, the EU has been highly inflexible; but, unless the issue, as a whole, is resolved, it is likely that other areas where cooperation could be advanced could be held back as well. In other words, the current inflexible policies of the EU and GCC member countries have served as an impediment to achieve broader political and economic goals.

The literature review and the EU-GCC trade data analyses (Tables 1, 2, and 3) suggest economic gains are not the dominant factor of past free trade negotiations and may not play an important role in the future as well. The EU has virtually no economic gains as a result of free trade, and the GCC economic gains are insignificant due to lack of competiveness of GCC industries. GCC countries are not ready to take an advantage of trade liberalization with the EU. The GCC is not a dominant trade partner to the EU, while the EU is only a major exporter to GCC countries comprising about $30 \%$ of total GCC imports. GCC countries' exports to the EU countries are primarily hydrocarbons and an insignificant percentage of total GCC exports.

The primarily motives behind FTA negotiations by both sides were geopolitical gains; thus, future FTA negotiations should focus on political, environmental, cultural, and security issues. The field of energy security and environmental protection offer another area of cooperation between EU and GCC member countries. There is a broad agreement on the need to move towards a post-Kyoto 2012 climate regime and achieve a comprehensive agreement in the future climate talks. At the same time, there is an opportunity to establish closer networks in the field of clean energy, the use of solar energy, and the possibility of advances in carbon capture sequestration whereby better use of expert networks and exchanges among institutions on both sides can be made. The announcement of Abu Dhabi as the new headquarter for the International Renewable Energy Agency (IRENA) offers a specific opportunity to engage with the GCC member countries on coordinated measures and approaches when it comes to the critical climate change debate. Here, discussions on the establishment of a joint EU-GCC energy technology center to undertake joint collaborative projects should be explored further. Additional efforts should also be put forward when it comes to research and study into carbon capture and sequestration.

Equally important is the realm of culture and public diplomacy, which will serve as the foundation for better understanding and exchange of views among people from both sides. More concrete plans need to be put in place in the area of student and academic exchange where little direct contact exists at this stage. Outside the economic and social aspects, the current political climate in both the regions and around the globe underscores the necessity for a reinvigorated commitment in EU-GCC relations. Security in the Gulf remains highly volatile. In conclusion, there is a need to focus on the most pressing issues at hand to formulate common approaches and policies; but, at the same time, for both sides there is a need for a fresh look at concluding an FTA not only focusing on economic gains.

\section{AUTHOR INFORMATION}

M. Anaam Hashmi is a full professor at the Minnesota State University, Mankato. His areas of expertise are currency operation, cross-border trade alliances, foreign direct investment, and sustainability-related policies of multinational corporations. Dr. Anaam Hashmi's international business involvement spans about twenty-five years. He has advised and consulted a number of businesses in formulating their foreign market entry strategies and crosscultural training programs. He has prepared feasibility studies pertaining to investing in the power generation sector

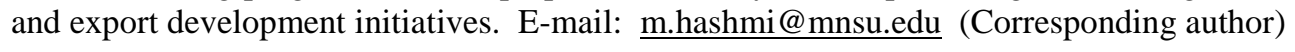

Fahad Al-Eatani is an Associate professor of Management at King Aldulaziz University, Saudi Arabia. Dr. AlEatani has vast experience in public sector and he has been involved in bilateral trade and cultural exchanges between the European Union and Saudi Arabia. He teaches international business courses at the graduate level and enjoys business projects dealing with trade negotiations. 
Fareed Shaikh is an Associate professor of Management at King Aldulaziz University, Saudi Arabia. He has done consultancy work with local business entities.

\section{REFERENCES}

1. Antkiewicz, A., \& Momani, B. (2009). Pursuing geopolitical stability through interregional trade: The EU's motives for negotiating with the Gulf Cooperation Council. Journal of European Integration, 31(2), 217235.

2. DeRosa, D. A., \& Kernohan, D. (2004). Measuring the economic impact of an EU-GCC Free trade agreement. CEPS Working Document, No. 206/July 2004, Centre for European Policy Studies.

3. Direction of Trade Statistics (2012). International Monetary Fund, December 2012. Washington, D.C.

4. Hinkle, L., Hoppe, M., \& Newfarmer, R. (2006). Beyond Cotonou: Economic partnership agreements in Africa. In R. Newfarmer (ed.), Trade, Doha, and development: A window into the issues (pp.263-276). Washington, D.C.: The World Bank.

5. Koch, D., \& Stenberg, L. (2010). The EU and the GCC: Challenges and prospects under the Swedish EU presidency. Dubai: Gulf Research Center. September 2010. Retrieved from http://www.grc.ae/?frm_module=contents\&frm_action=detail_book\&frm_type_id=\&op_lang=e+\%3E+The + EU+and+the+GCC:+Challenges+and+Prospects+under+the+Swedish+EU+Presidency\&sec=Contents\&fr m_title $=\&$ book_id $=70877$

6. Nonneman, G. (2006). EU-GCC relations: Dynamics, patters, and perspectives. Dubai: Gulf Research Center. June 25, 2006. Retrieved from http://www.grc.ae/index.php?frm_module=contents\&frm_action=detail_book\&frm_type_id=\&op_lang=en \&overri $\mathrm{e}=$ Research + Papers $+\% 3 \mathrm{E}+\mathrm{EU}-$ GCC+Relations\%3A+Dynamics\%2C+Patterns+\%26+Perspectives\&sec $=$ Contents\&frm_title=\&book_id $=1$ 8258

7. Persson, M. (2008). Trade facilitation and the EU-ACP economic partnership agreements. Journal of Economic Integration, 23(3), 518-546.

8. Price Waterhouse Coopers (2004). Sustainability Impact Assessment (SIA) of the negotiations of the trade agreements between the European community and the countries of the Cooperation Council of the Cooperation Council for the Arab States of the Gulf (GCC). Final Report. May 30, 2004. Retrieved from http://trade.ec.europa.eu/doclib/docs/2005/january/tradoc_121208.pdf

9. The Cooperation Council (2009). Cooperation between the European community and GCC. $19^{\text {th }}$ EU-GCC Joint Council and Ministrial Meeting, Muscat. April 29, 2009. Retrieved from http://www.consilium.europa.eu/uedocs/cmsUpload/107449.pdf

10. Toledo, H. (2011). EU-GCC free trade agreement: Adjustments in a factor proportion model for the UAE. International Review of Economics and Finance, 20(2), 248-256. Retrieved from http://ideas.repec.org/a/eee/reveco/v20y2011i2p248-256.html 


\section{APPENDIX}

The EU Trade Agreements and Tariff Concessions

\begin{tabular}{|c|c|}
\hline Type of Preferences & Countries \\
\hline EU Custom Unions & San Marino, Vatican, Andorra, Feroe Islands, Turkey \\
\hline EU Free Trade Agreements & 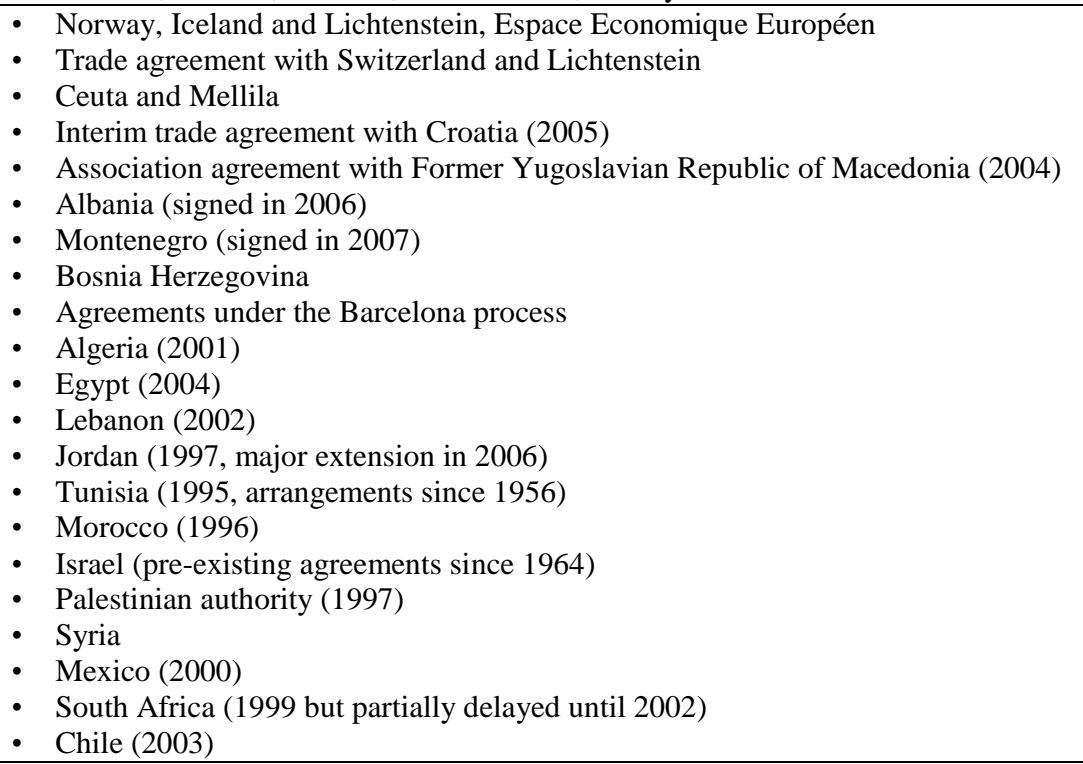 \\
\hline Other Concessions & $\begin{array}{l}\text { - GSP, including the Everything But Arms component for LDCs and GSP+ (mainly } \\
\text { Central America and Andean countries). } \\
\text { - Cotonou agreement with ACP countries } \\
\text { - Overseas territories }\end{array}$ \\
\hline
\end{tabular}

Source: (Hinkle, Hoppe, \& Newfarmer, 2006) 